\title{
IRYNA PROTSYK
}

ORCID: 0000-0001-8472-0141

Narodowy Uniwersytet „Akademia Kijowsko-Mohylańska”

Wydział Humanistyczny, Katedra Języka Ukraińskiego

\section{Nazwy ukraińskich drużyn piłkarskich z perspektywy historycznej}

\begin{abstract}
Abstrakt
W artykule przeanalizowano nazwy drużyn piłkarskich z perspektywy ponad stu lat historii futbolu na Ukrainie. Przedstawiono nazwy własne oraz słownictwo apelatywne, które stało się podstawą motywacyjną do nominacji ukraińskich drużyn piłkarskich. Wśród onimów są nazwy państwa narodowego, nazwy etnograficznych regionów Ukrainy, nazwy miejscowości - miast, miasteczek, wsi, historycznie ważne toponimy, hydronimy, oronimy, antroponimy, nazwy stowarzyszeń sportowych i przedsiębiorstw. Mniejsza grupa to nazwy apelatywne: nominacje symboli państwowych i narodowych Ukrainy, nazwy terenów typowych dla Ukrainy, nominacje zwierząt, roślin, a także nazwy mieszkańców różnych regionów Ukrainy, nazwy osób wykonujących różne zawody lub różną działalność, nazwy odnoszące się do produkcji przedsiębiorstw. Na podstawie analizy motywacji tych nominacji wykazano, iż dzięki wpływom narodowym, które zadecydowały o wyborze nazw drużyn piłkarskich, zachowana jest ciągłość tradycji narodowych i kulturowych w nominacji.
\end{abstract}

Słowa kluczowe: onomastyka, nazwy własne ukraińskich drużyn piłkarskich, motywacja nazw drużyn, onim, leksyka apelatywna.

W języku ukraińskim, podobnie jak w innych językach, nazwy własne ilościowo przeważają nad słownictwem apelatywnym. Szczególne miejsce wśród nazw własnych zajmują nominacje zespołów piłkarskich, określające ważki segment świata współczesnego, w którym piłka nożna zajmuje szczególne miejsce. Celem niniejszej pracy jest przedstawienie nazw ukraińskich drużyn piłkarskich na przestrzeni ponadstuletniej historii piłki nożnej na Ukrainie (koniec XIX - początek XXI wieku). Źródłem materiału faktograficznego były czasopisma sportowe, które ukazywały się w języku ukraińskim. Nazwy drużyn piłkarskich nie były dotychczas przedmiotem szczegółowych opisów w onomastyce ukraińskiej, z tego też względu są godne odrębnych badań. W ostatnich latach opublikowano kilka opracowań na temat nazw drużyn piłkarskich, między innymi artykuły Natalii Hryhoruk o nominacjach bia- 
łoruskich, rosyjskich i ukraińskich drużyn piłkarskich (Григорук 2013: 8-12), nazwach polskich klubów piłkarskich (Григорук 2014: 28-40), artykuł Marka Olejnika o nazwach polskich i ukraińskich drużyn piłkarskich (Олейнік 2014: 198-207), jak również artykuły autorki niniejszego tekstu - o nazwach ukraińskich drużyn piłkarskich Galicji w pierwszej połowie XX wieku (Процик 2016: 122-129) i o nazwach ukraińskich klubów piłkarskich w okresie sowieckim (Процик 2016: 62-68). Cele proponowanego badania są następujące: 1) zademonstrować, jakie nazwy nosiły ukraińskie kluby piłkarskie od końca XIX do początku XXI wieku; 2) przeanalizować, od jakich leksemów tworzone były nazwy zespołów piłkarskich, i sklasyfikować te nominacje według kryterium motywacji; 3) wykazać wpływ czynników narodowych, totalitarnych i posttotalitarnych, jak również komercyjnych na wybór nazw klubów piłkarskich na przestrzeni XX-XXI wieku.

\section{Nazwy ukraińskich drużyn piłkarskich w Galicji pod koniec XIX - i w pierwszym ćwierćwieczu XX wieku}

Te nazwy miały złożoną strukturę, która łączyła w sobie komponent-skrót (S.T. ${ }^{1}-$ towarzystwo sportowe, S.K. ${ }^{2}$ - klub sportowy, U.S.K. ${ }^{3}$ - ukraiński klub sportowy, U.S.T. ${ }^{4}$ - ukraińskie towarzystwo sportowe, U.R.S.K. ${ }^{5}$ - ukraiński robotniczy klub sportowy) oraz sam onim. Składniki onimiczne złożonych nazw ukraińskich drużyn piłkarskich Galicji były motywowane zarówno onimami, jak i apelatywami.

\subsection{Nazwy galicyjskich drużyn piłkarskich motywowane onimami}

Wiele klubów wykorzystało w nazwie toponimy - nominacje miast, miasteczek, wsi, z których wywodzi się klub, na przykład: U.S.K. „Dobromyl”, S.K. „Dobrjany”, U.R.S.K. „Kołomyja”, S.K. „Załuże”, S.K. „Pawelcze”, U.S.K. „Stanislawiw”, S.K. „Toporiwci”, U.S.T. „Chodoriw”, U.S.K. „Yamnycja”. Nazwy etnograficznych regionów Ukrainy odzwierciedlono w nazwach galicyjskich drużyn U.S.T. „Podilla” Ternopil i U.S.T. „Pidhirja” Drohobycz, reprezentujących te dwa regiony. Towarzystwo Sportowe S.T. „Ukraina” Lwiw wzięło swoją nazwę od nominacji państwa Ukraina. Podkreślało w ten sposób przynależność sportowców do narodu ukraińskiego, co w panujących wówczas warunkach bezpaństwowości było demonstracją patriotyzmu, odwagi oraz siły ducha. Analogicznymi czynnikami umotywowany został

${ }^{1}$ Ukr. С.Т. - Спортове товариство, pol. Towarzystwo sportowe.

2 Ukr. С.К. - Спортовий клюб, pol. Klub sportowy.

${ }^{3}$ Ukr. У.С.К. - Український спортовий клюб, pol. Ukraiński klub sportowy.

${ }^{4}$ Ukr. У.С.Т. - Українське спортове товариство, pol. Ukraińskie towarzystwo sportowe.

${ }^{5}$ Ukr. У.Р.С.К. - Український робітничий спортовий клюб, pol. Ukraiński robotniczy klub sportowy. 
także wybór nazwy zakarpackiej drużyny piłkarskiej - S.K. „Ruś” Użhorod, która wykorzystała w swojej nominacji dawną nazwę Ukrainy — Ruś.

Oprócz toponimów związanych z obszarami, na których powstały i funkcjonowały kluby piłkarskie, w nazwach zespołów często znajdowały odzwierciedlenie te nazwy miejscowości, które są ważne dla ukraińskiej tożsamości narodowej i wykazują ciągłość pamięci historycznej i tradycji kulturowych, przede wszystkim U.S.K. „Baturyn” Peremyszl — od nazwy stolicy hetmana Iwana Mazepy, miasta Baturyn (Янко 1998: 35). Od nazwy Sicz Zaporoska (Янко 1998: 142) — oznaczającej społeczno-polityczną i wojskowo-administracyjną jednostkę ukraińskich Kozaków, która znajdowała się w południowej części Ukrainy, za porohami na Dnieprze utworzono nazwy takich galicyjskich klubów piłkarskich, jak S.T. „Sicz” Dobrjany i S.K. „Zaporożeć” Nyżankowyczi. Nazwę lwowskiego klubu piłkarskiego U.S.K. "Czornomorci” też powiązać należy z odniesieniem historycznym do Czornomorskiej Siczy. Jeszcze jednym leksemem, tematycznie pasującym do nominacji opisanych powyżej, jest nazwa geograficzna Chortycja (Янко 1998: 376) - nominacja największej wyspy na Dnieprze (w pobliżu jej północnego brzegu znajdowały się ogromne kamienne porohy — rodzaj wodospadów), posiadłości Siczy Zaporoskiej; wykorzystano ją przy nadawaniu nazw klubom piłkarskim U.S.T. „Chortycja” z Borszczowa, Żydaczowa oraz Lubaczowa.

Wśród nominacji ukraińskich klubów piłkarskich osobną grupę tworzą nazwy motywowane onimami różnych obiektów geograficznych: wodnych oraz górskich. Wśród hydroni mów do nominacji galicyjskich drużyn piłkarskich używane były nazwy rzek płynących przez tereny, z których wywodziły się kluby sportowe, na przykład: U.S.K. „Bystrycja” Nadwirna - z miasta Nadwórna, położonego nad brzegiem Bystrzycy Nadwórniańskiej (Bystryci Nadwirnianśkoji) (Словник гiдронімів України 1979: 50), U.S.T. „Prut” Delatyn — z miasteczka, w którego pobliżu znajduje się rzeka Prut (ibidem: 251), U.S.K. „Sjan” Peremyszl - z miasta Przemyśl, które leży na obu brzegach Sanu (Sjanu) (ibidem: 551), U.S.K. „Wihor” Nyżankowyczi - z miasteczka Niżankowice, przez które przepływa prawy dopływ Sanu rzeka Wihor (ibidem 1979: 106). Nadsański klub piłkarski S.K. „Zbrucz” Oleszyczi w nazwie wykorzystał hydronim, będący symbolem podziału Ukrainy na dwa państwa - nazwę rzeki Zbrucz, wzdłuż której wytyczono granicę (ibidem: 209). Dwa zespoły z miejscowości koło Lwowa w swoich nazwach odzwierciedliły bliskość względem największej rzeki regionu — Dniestru (ibidem: 173-174) - U.S.T. „Dnister” Sambir i U.S.T. „Dnister” Mykołajiw. Klub piłkarski z miasteczka Winniki w nazwie wykorzystał nazwę własną największej ukraińskiej rzeki Dniepr (Dnipro) (ibidem: 173) - U.S.K. „Dnipro” Wynnyky. Wśród or o nimó w, które znalazły odzwierciedlenie w nominacjach galicyjskich drużyn piłkarskich, były między innymi: U.S.K. „Łysonia” Bereżany - pochodząca od nominacji góry Łysonia w pobliżu miasta Brzeżany; S.T. „Czornohora” Stanislawiw — od nazwy Czornohora - najwyższego pasma ukraińskich Karpat; S.K. „Howerla” Stanislawiw — nazwy najwyższego szczytu w Karpatach - Howerly, położonego w paśmie górskim Czornohora. 
Odrębną grupą nazw własnych, które stały się podstawą motywacyjną do nominacji ukraińskich klubów piłkarskich, są antrop onimy utworzone od imion oraz nazwisk (pierwotnie przezwisk, zawołań) znanych i ważnych dla Ukraińców postaci historycznych. Nominacja klubu piłkarskiego U.S.K. „Roksolana” Rohatyn wiąże się z legendą o Nastii (Anastazji) Lisowskiej, która później została żoną sułtana Imperium Osmańskiego Sulejmana Wspaniałego - Roksolaną, pochodzącą z Rohatyna. Kilka klubów piłkarskich wybrało jako nazwę imiona znanych $\mathrm{z}$ historii ukraińskich powstańców: Oleksego Dowbusza - lidera buntowników w Karpatach - U.S.T. „Dowbusz” Kołomyja i Ustyma Karmeluka - przywódcę ruchu powstańczego na Podolu - U.S.K. „Karmeljuk” Korownyky. Cztery galicyjskie zespoły wykorzystały nazwisko wojskowego i politycznego działacza czasów Bohdana Chmielnickiego, dowódcy kozackiego wojska zaporoskiego Iwana Bohuna. To zespoły U.S.K. „Bohun” ze Lwowa, z Brodów i z miejscowości Komarno oraz ze wsi Serafińce koło Horodenki - S.K. „Bohun” Serafynci. Nominacja U.S.T. „Czernyk” Stanislawiw związana jest z kolei z najnowszą historią Ukrainy. Nazwa klubu piłkarskiego została nadana na cześć Fedora Czernyka, poległego w roku 1918, skauta, setnika Legionu Ukraińskich Strzelców Siczowych. Jako nazwa własna klubu piłkarskiego funkcjonował też antroponim z historii starożytnej - imię trackiego wojownika, przywódcy buntu niewolników przeciwko Rzymianom Spartakusa. Imię to stało się podstawą motywacyjną do nazwania ukraińskiego klubu piłkarskiego U.R.S.K. „Spartak” Peremyszl.

Oryginalna jest nominacja drużyny piłkarskiej S.T. „Rusałka” Zołocziw — od onimu „Rusałka Dniestrowa” - nazwy pierwszego ukraińskiego almanachu, przygotowanego przez ukraińskich pisarzy i działaczy publicznych: Markijana Szaszkewycza, Iwana Wahylewycza oraz Jakowa Holowaćkoho i opublikowanego w roku 1848 w Budapeszcie.

\subsection{Nazwy galicyjskich drużyn piłkarskich motywowane leksyką apelatywną}

Znaczną grupę nazw drużyn piłkarskich obejmują nominacje motywowane nazwami apelatywnymi, wśród których wyróżniają się nazwy zjawisk naturalnych: S.K. „Burewij” Lwiw, S.K. „Burewij” Buczacz, S.K. „Burewij” Pasiczna - od burewij ‘burza'; U.S.K. „Zahrawa” Stanislawiw — od zahrawa 'poświata'; S.K. „Wychor” Jamnycja - od leksemu wychor 'trąba powietrzna'; S.K.„Churtowyna” Komarno - od słowa churtowyna 'silne wiatry i śnieg, zamieć' (Великий тлумачний словник сучасної украӥнської мови 2001: 1356); S.K. „Kometa” Lwiw — od terminu kometa; U.S.K. „Zoria” Lwiw, U.S.K. „Zoria” Chodoriw — od leksemu zoria 'gwiazda'.

Nazwy, które wskazują na obszary naturalne charakterystyczne dla Ukrainy oraz na cechy terenów górskich, to: U.S.K. „Step” Buszkowyczi - pochodząca od nazwy apelatywnej step, nazwy naturalnego obszaru w umiarkowanych szerokościach geograficznych, obejmującego sporą część terytorium Ukrainy; U.S.K. „Skała” Stryj, 
U.S.K. „Skała” Mostyśka — od starej nazwy zwyczajowej skała; S.T. „Płaj” Lwiw — od dialektowego leksemu płaj, który oznacza spłaszczony grzbiet gór z pastwiskami i ścieżkami w Karpatach; U.S.T. „Beskyd” Nadwirna, U.S.K. „Beskyd” Turka, S.K. „Beskyd” Probiżna — od leksemu beskyd 'góra, skała', będącego nazwą systemu pasm górskich w północnej strefie Karpat.

W nazwach drużyn piłkarskich wskazano również na nazwy mieszkańców albo ro d zajwykonywanego przez nich zawo du. Zespół z Sanoka, który należy do etnograficznego regionu Łemkowszczyna, użył nazwy mieszkańców tego regionu — Łemków - U.S.K. „Łemko” Sianok. Borysławski zespół piłkarski w nazwie U.S.T. „Ropnyk” Borysław podkreślił dominujące zajęcie mieszkańców przemysłowego regionu Galicji na przełomie XIX-XX wieku, czyli wydobywanie ropy naftowej.

Dość liczną, ale niezbyt zróżnicowaną grupę stanowią nominacje drużyn piłkarskich motywowane nazwami ptaków. Ponad dwadzieścia klubów piłki nożnej użyło w nazwie leksemu sokit, co jest całkiem naturalne, ponieważ najstarszym ukraińskim stowarzyszeniem sportowym było Gimnastyczne Towarzystwo Sportowe „Sokół”. Nazwę U.S.K. „Sokił” nosiły między innymi zespoły z takich galicyjskich miast i wsi: Bóbrka, Bohorodczany, Bodnarów, Gliniany, Drohobycz, Zawadów, Złoczów, Kołomyja, Koniuchów, Krasne, Kuty, Lwów, Nakonieczne I, Nakonieczne II, Otynia, Podhajce, Przemyśl, Rohatyn, Skole, Stanisławów, Stryj, Sądowa Wiśnia, Trzębowla, Chodorów, Wasylkowce, Jaworów. Nazwy stowarzyszenia sportowego i drużyn piłkarskich związane z leksemem sokit odnoszą się do drapieżnego ptaka z rodziny sokołowatych, będącego symbolem odwagi, męskości oraz siły. Do nominacji galicyjskich drużyn piłkarskich używano również leksemu czajka, oznaczającego 'ptaka morskiego z rodziny mewowatych'. Chociaż jest to rzadki ptak w Galicji, to jednak zoon im ten obecny jest w nazwach kilku zespołów - U.S.K. „Czajka” Kałusz, S.K. „Czajka” Towmacz, S.K. „Czajka” Czortkiw. Wynika to prawdopodobnie $\mathrm{z}$ aktywnego używania tego leksemu w folklorze ukraińskim. Leksem berkut 'orzeł przedni', oznacza nazwę dużego ptaka drapieżnego z rodziny jastrzębiowatych. Jest on symbolem odwagi, wytrzymałości, siły i jego nazwę wykorzystano do nazwania drużyny piłkarskiej z Przemyśla - U.S.K. „Berkut” Peremyszl.

Odrębna grupa nominacji klubów piłkarskich to leksemy semantycznie powiązaneznazwami ukraińskich symboli i pojęć państwowych oraz narodowych. Nazwa ukraińskiego narodowego godła tryzub została odzwierciedlona w nominacji klubu piłkarskiego U.S.K. „Tryzub” Lwiw. Jednist, jedność, czyli “ścisły związek, spójność, integralność i niepodzielność ukraińskich regionów etnicznych, które na początku XX wieku należały do różnych państw, oraz marzenia ukraińskiego społeczeństwa o połączeniu tych obszarów w jednym państwie narodowym wyraża się w nazwie zespołu piłkarskiego S.K. „Jednist” Horodenka. Kalina jako narodowy symbol Ukrainy stała się podstawą motywacyjną nazwy klubu piłkarskiego S.K. „Kalyna” Żurawno.

Podsumowując: na przełomie XIX i XX wieku jako podstawę motywacyjną nazw galicyjskich drużyn piłkarskich spośród onimów wykorzystano nazwy miejscowo- 
ści, historycznie ważne toponimy, hydronimy, oronimy i antroponimy, a spośród leksyki apelatywnej - nazwy zjawisk przyrody, obszarów naturalnych, ptaków, nazwy topograficzne, nazwy symboli państwowych i narodowych. Większość nominacji związana jest $\mathrm{z}$ ukraińskimi realiami historycznymi, geograficznymi i kulturowymi, co jest dowodem skrupulatnego doboru reprezentatywnych nazw dla klubów piłkarskich.

\section{Nazwy ukraińskich drużyn piłkarskich od lat dwudziestych do lat osiemdziesiątych XX wieku}

Podczas analizy nazw trudno nie zauważyć, że nominacje te bardzo się różnią od nazw klubów piłkarskich w Galicji na przełomie XIX-XX wieku. Tylko 20\% ukraińskich klubów piłkarskich nosiło nazwy związane z historią i kulturą Ukrainy, a 80\% - to nominacje noszące piętno sowieckiej rzeczywistości.

2.1. Nazwy ukraińskich klubów piłkarskich od lat dwudziestych do lat osiemdziesiątych XX wieku motywowane onimami

Jedna trzecia ukraińskich klubów piłkarskich tego okresu miała nazwy będące powieleniem nazw najbardziej popularnych zrzeszeń czy stowarzyszeń sportowych — zespoły „Dynamo” (od „Dynamo” - zrzeszenie sportowe czekistów, później - stowarzyszenie wychowania fizycznego i sportu organów ścigania: Ministerstwa Spraw Wewnętrznych i Komitetu Bezpieczeństwa Państwowego, KGB) działały w miastach: Kijów ${ }^{6}$, Biała Cerkiew, Woroszyłowgrad ${ }^{7}$, Dniepropietrowsk, Żytomierz, Irpień, Lwów, Łuck, Mikołajów, Odessa, Proskuriw/Chmielnicki ${ }^{8}$, Tarnopol, Równe, Sumy, Użhorod, Charków, Czerniowce, Czernihów; zespoły „Spartak” (od „Spartak” - zrzeszenie sportowe pracowników przemysłu, spółek komunalnych, komunikacji, transportu drogowego, jak również kultury, edukacji, medycyny i handlu) utworzono w Białej Cerkwi, Wierchniodnieprowsku, Dniepropietrowsku, Drohobyczu, Żytomierzu, Kijowie, Krzywym Rogu, Lwowie, Nikopolu, Połtawie, Samborze, Stanisławowie/Iwano-Frankowsku, Sumach, Użhorodzie, Charkowie, Chersoniu; zespoły o nazwach „Lokomotyw” (od „Lokomotyw” - dobrowolne zrzeszenie sportowe związków zawodowych pracowników transportu kolejowego

${ }^{6} \mathrm{Na}$ liście miejscowości, w których istniały drużyny piłkarskie o tej samej nazwie, jako pierwsze podane zostały miasta, $\mathrm{z}$ których zespoły dotychczas zachowały swoje nazwy, a następnie pozostałe toponimy.

${ }^{7} \mathrm{~W}$ tekście podano ten toponim, który funkcjonował w czasach sowieckich oraz był elementem złożonej nazwy zespołu; ze względu na ekonomię wywodu nie podano współczesnych wariantów tych nazw miast.

${ }^{8}$ Niektóre nazwy drużyn piłkarskich uległy zmianie ze względu na zmiany nazwy miast w okresie sowieckim; informację tę podano w tekście po ukośniku. 
i metra) założono w miastach: Winnica, Dniepropietrowsk, Zaporoże, Znamianka, Iwano-Frankowsk, Kijów, Kotowsk, Lwów, Odessa, Równe, Synelnykowe, Smiła, Stalino/Donieck, Stryj, Charków, Chersoń, Jasynuwata; zespoły „Zenit” (od „Zenit” - zrzeszenie sportowe pracowników przemysłu maszynowego) zostały utworzone w Charkowie i Stalino; kluby „Torpedo” (od „Torpedo” - zrzeszenie sportowe pracowników przemysłu samochodowego, lotniczego oraz produkcji ciągników) były w miastach: Berdiańsk, Zaporoże, Kirowohrad, Łuck, Odessa, Teodozja; zespół „Trudowi rezerwy” (od „Trudowi rezerwy”, rezerwy siły roboczej — stowarzyszenie sportowe pracowników oświaty technicznej) istniał w Woroszyłowgradzie/ Ługańsku; zespoły „Kolos” (od „Kolos”, kłos - ukraińskie stowarzyszenie wychowania fizycznego i sportu robotników rolnych) utworzono w Akymowce, Horodku, Kiwercach, Nikopolu, Osokorowcach, Pawłogrodzie, Podhorodnem, Połtawie; zespoły „Awanhard” (od „Awanhard” - ukraińskie dobrowolne zrzeszenie sportowe związków zawodowych robotników przemysłowych i budownictwa) funkcjonowały w miastach: Antracyt, Wolnogórsk, Gorłówka, Dniepropietrowsk, Dobromil, Żdanów, Żółte Wody, Żydaczów, Kercz, Kramatorsk, Krzywy Róg, Lwów, Makiejewka, Mikołajów, Nowowołyńsk, Ordżonikidze, Równe, Rowieńki, Symferopol, Sumy, Terny, Tarnopol, Charków, Czerniowce; zespoły „Burewisnyk” (od „Burewisnyk" - sportowe stowarzyszenie uniwersytetów i instytucji badawczych) były w Wynohradowie i Mukaczewie. Nominacjami wojskowych stowarzyszeń sportowych - CSKA, SKA i SKCZF - motywowane były także nazwy drużyn piłkarskich, tworzonych przy wojskowych stowarzyszeniach sportowych, między innymi: CSKA - Centralny Sportowy Klub Armii (Kijów); BCZA - Budynek [Dom] Armii Czerwonej / OBCZA - Okręgowy Budynek Armii Czerwonej / OBO - Okręgowy Budynek Oficerów / BO - Budynek Oficerów / SKWO - Klub Sportowy Okręgu Wojskowego / SKA - Sportowy Klub Armii (Kijów, Lwów, Odessa); BOF - Budynek [Dom] Oficerów Floty (Sewastopol) / SKF - Klub Sportowy Floty / SKCZF - Klub Sportowy Floty Czarnomorskiej.

Dużą grupę nazw drużyn piłkarskich obejmują nominacje motywowane ergonimami- nazwami przedsiębiorstw, przy których funkcjonowały owe zespoły: "Azowstal" Żdanow - od nazwy mariupolskiego (sowiecka nazwa Mariupola to Żdanów) koncernu metalurgicznego Azowstal; „Arsenał” Kyjiw — od nazwy kijowskiej fabryki wojskowych i cywilnych urządzeń Arsenał; „Bilszowyk” Kyjiw — od nazwy kijowskiej fabryki Bilszowyk, produkującej maszyny; „Electron” Mostyśka — od nazwy mościskiego oddziału lwowskiej fabryki telewizorów Elektron; „Zawod imeni Illicza" Mariupol — od nazwy mariupolskiej fabryki metalurgicznej imienia Illicza [Lenina - I.P.]; „Kation” Chmelnyćkyj — od nazwy chmielnickiej fabryki Kation - producenta katodowej i anodowej folii oraz kondensatorów, komponentów elektrycznych i radiowych (Підприємства України: www.ua-region.com.ua); „Koksochimzawod” Horliwka - od nazwy przedsiębiorstwa chemicznego w Gorłówce produkującego koks; „Kolormet” Artemiwsk, Zaporiżżja — od nazw zakładów Kolormet w Artemowsku i Zaporożu, zajmujących się przetwórstwem metali 
kolorowych; „Krymspecbud” Jałta — od kombinatu Krymspecbud w Jałcie; „Krystal” Cherson — od nazwy chersońskiej fabryki urządzeń półprzewodnikowych Krystal; „Odesahruntomasz" Odesa - od nazwy zakładu Odesahruntomasz produkującego maszyny wykorzystywane w rolnictwie i leśnictwie; „Pres” Dnipropetrowśk — od nazwy dniepropietrowskiego zakładu hutniczego PresTechMasz; „Prohres” Berdycziw - od nazwy berdyczowskiej fabryki Prohres produkującej maszyny; „Silmasz” Lwiw, Charkiw, Zaporiżżja, Kowel - od nazw przedsiębiorstw producentów maszyn dla rolnictwa Lwiwsilmasz, Kowelsilmasz oraz przedsiębiorstw Silmasz w Charkowie i Zaporożu; „Tytan” Zaporiżżja — od nazwy kombinatu tytano-magnezowego w Zaporożu; „Traktornyj zawod” Charkiw — od nazwy fabryki ciągników w Charkowie; „Centrolit” Sumy — od nazwy fabryki Centrolit w Sumach, zajmującej się produkcją stali.

Odrębną grupę tworzą nazwy drużyn piłkarskich motywowane antroponima mi - nazwiskami przywódców bolszewickich: „Dzerżyneć” Charkiw — nazwa „Metalista” z Charkowa w latach 1946-1956, „Dzerżyneć” Woroszyłowhrad — jedna z nazw Zori Luhanśk, pochodzące od nazwiska czekisty Feliksa Dzierżyńskiego;. "Stachanoweć” Stalino - pierwsza nazwa „Szachtara” z Doniecka, nadana ku czci przodownika pracy Aleksandra Stachanowa; „Frunzeneć” Sumy - nazwa piłkarskiego zespołu z Sum, utworzona od nazwiska przywódcy radzieckiego Michaiła Frunze.

\subsection{Nazwy ukraińskich drużyn piłkarskich od lat dwudziestych do lat} osiemdziesiątych XX wieku motywowane leksyką apelatywną

Dużą grupę tworzą nominacje motywowane nazwami zawodów, rodzajem działalności czy typem zajęć lub nazwami osób wykonujących jakiś zawód.

Zespoły „Szachtar” (od szachtar 'górnik pracujący w kopalni' (Великий тлумачний словник сучасної української мови 2001: 1391) były w miastach Stalino/ Donieck; Gorłówka, Dzierżyńsk, Kadijewka/Stachanow, Krasnyj Łucz, Makiejewka, Ordżonikidze/Jenakijewe, Pawłohrad, Rutczenkowe, Swierdłowsk, Torez; Nowowołyńsk, Czerwonogród; Aleksandria; Korostyszów, Marganiec.

Nazwę „Hirnyk” (od hirnyk 'pracownik przemysłu górniczego' (ibidem: 183) nosiły zespoły z miast: Krzywy Róg, Pawłohrad i Nowojaworowsk, z kolei nominację „Metalurh" (od metalurg 'specjalista od metalurgii', ibidem: 521) - zespoły z miast: Dniepropietrowsk, Dnieprodzierżyńsk, Zaporoże, Krzemieńczuk, Nikopol, Charków, Odessa i Kupiańsk. Nazwę „Metalist” (od metalist 'pracownik przemysłu metalowego', ibidem: 520) nosiły kluby z Charkowa, Dniepropietrowska, Stalino/Doniecka. Nominację „Chimik" (od chimik 'pracownik przemysłu chemicznego', ibidem: 1344) odnotowano w miastach o rozwiniętym przemyśle chemicznym: Dniepropietrowsk, Kałusz, Pawłohrad, Siewierodonieck, Czerkasy. Nazwy „Naftowyk” (od naftowyk 'ekspert przemysłu naftowego', ibidem: 587) miały zespoły piłkarskie z miast, 
w których działały rafinerie, takich jak Borysław, Dolyna, Drohobycz, Ochtyrka, Chersoń. Nominacja „Awtomobilist”(od awtomobilist 'osoba zaangażowana w motoryzację, ibidem: 5) występowała w zespołach z Zaporoża, Żytomierza, Lwowa, Połtawy. Nazwę „Maszynobudiwnyk” (od maszynobudiwnyk 'specjalista od produkcji maszyn', ibidem: 515) odnotowano w zespołach z Artemowska, Borodzianki, Dniepropietrowska, Kijowa. Nominacja "Kombajnobudiwnyk” (od kombajnobudiwnyk 'specjalista w dziedzinie produkcji kombajnów', ibidem: 443) używana była przez klub z Tarnopola, gdzie funkcjonowała fabryka produkująca kombajny do zbioru buraków.

Zespół z Mikołajowa, gdzie funkcjonuje największa stocznia na Ukrainie, otrzymał nazwę „Sudnobudiwnyk" (od sudnobudiwnyk 'pracownik przemysłu stoczniowego, specjalista stoczniowiec', ibidem: 1213). Nominację „Budiwelnyk” (od budiwelnyk 'ten, który coś buduje, pracujący na budowie', ibidem: 65) nosiły kluby z Dnieprodzierzyńska, Dniepropietrowska, Krzywego Rogu, Kuzniecowska, Połtawy, Prypeci. Zespoły z Berehowego, Brzeżan, Bóbrki, Połtawy, Równego, Czerkas nazywały się „Kolhospnyk”, rolnik, (od kolhospnyk 'członek kolhospu - kolektywnego gospodarstwa rolnego', ibidem: 439). Nazwę „Papirnyk” jako jedyny nosi zespół z Malina, gdzie od końca XIX wieku znajduje się jeden z największych w Europie zakładów papierniczych (od papirnyk 'pracownik przemysłu papierniczego', ibidem: 703). Zespół „Cementnyk” działa w mieście Mikołajów koło Lwowa, gdzie funkcjonuje cementownia (od cementnyk 'pracownik przemysłu cementowego', ibidem: 1360). Drużyny z Winnik, Dniepropietrowska, Lwowa i Odessy nazywały się „Charczowyk” (od charczowyk 'pracownik przemysłu spożywczego', ibidem: 1340). Zespół "Cukrowyk" pochodził z miasta Chodorów, gdzie istniała cukrownia (od cukrowyk 'pracownik przemysłu cukrowniczego', ibidem: 1367). Nominację „Tekstylnyk” wybrała drużyna z Doniecka (od tekstylnyk 'pracownik przemysłu włókienniczego', ibidem: 1235). Z nazwą „Szkirjanyk” zaś występował zespół z Berdyczowa, gdzie pod koniec XIX wieku założono jedną z największych garbarni na Ukrainie (od szkirjanyk, garbarz 'specjalista branży skórzanej', ibidem: 1399). Nazwę „Trubnyk” nosił zespół przy Południowej Fabryce Rur w Nikopolu (od trubnyk 'specjalista od produkcji rur'). Pod nazwą „Hazowyk” występował w lidze zespół z Komarnego, gdzie działa przedsiębiorstwo wydobycia gazu (od hazowyk, haziwnyk 'pracownik przemysłu gazowego'). Nazwę „Radyst” nosił zespół w Kirowohradzie, gdzie funkcjonowała fabryka produkująca radia (od radyst 'radiooperator', 'ekspert w dziedzinie transmisji i odbioru komunikatów w radiu').

Osobną grupę tworzą nazwy zespołów motywowane apelatywami nazywającymi produkcję przedsiębiorstw: „Ekran” Szostka - zespół zakładu chemicznego w Szostce, produkującego taśmy kinowe oraz filmowe; „Enerhija” Nowa Kachowka - zespół elektrowni wodnej w Kachowce; „Industrija” Jenakijewe - zespół giganta przemysłowego, fabryki metalurgicznej w Jenakijewem; „Pidszypnyk” Łućk - zespół zakładu produkującego łożyska w Łucku; „Silhosptechnika” Nikopol — zespół fabryki maszyn rolniczych w Nikopolu; „Stal” Dnipropetrowśk, Dniprodzerżynśk 
— zespoły zakładu metalurgicznego w Dnieprodzerżyńsku i zakładu produkcji rur w Dniepropietrowsku; „Tytan” Wilnohirśk - zespół koncernu górniczo-metalurgicznego w Wilnohorsku, producenta tytanu; „Traktor” Charkiw — zespół fabryki ciągników w Charkowie; „Transformator” Zaporiżżja - zespół fabryki transformatorów w Zaporożu (Підприємства України: www.ua-region.com.ua).

Duża liczba nazw klubów piłkarskich odzwierciedla ideologię sowiecką. To przede wszystkim nominacje motywowane nazwami mieszkańców miast, których nazwy zostały zmienione w czasach sowieckich: „Komunareć” Komunarśk - od komunareć 'mieszkaniec Komunarska' (zideologizowana, od leksemu komuna, nazwa Ałczewska); „Perwomajeć” Perwomajśk — od perwomajeć 'mieszkaniec Perwomajska', miasta nazwanego ku czci święta pierwszego maja; „Stachanoweć” Stachanow - od stachanoweć 'mieszkaniec Stachanowa' (dawna nazwa miasta Kadijewka, nazwanego ku czci Aleksandra Stachanowa - rekordzisty wydajności pracy w kopalni).

Osobną grupę tworzą nominacje motywowane nazwami pracowników przedsiębiorstw. W złożonych nazwach tych przedsiębiorstw znajdują się onimy o charakterze ideologicznym - nazwiska przywódców komunistycznych: „Kiroweć” Makijiwka - jedna z nazw „Szachtara” z Makiejewki, od leksemu kiroweć 'pracownik fabryki imienia Kirowa' (przedsiębiorstwo nazwane ku czci komunistycznego przywódcy Sergieja Kirowa); „Petroweć” Dnipropetrowśk - jedna z nazw klubu „Dnipro” z Dniepropietrowska - od leksemu petroweć 'pracownik zakładu metalurgicznego imienia Pietrowskiego' (od nazwiska przywódcy bolszewików Hryhorija Pietrowskiego). Skutkiem wpływu totalitaryzmu na wybór nazw jest nadanie zespołom z Zaporoża i Berdiańska nazwy „Kryła Rad”, motywowanej ideologicznym idiomem czasów sowieckich — „skrzydła rad”.

Podsumowując: jako nominacje ukraińskich drużyn piłkarskich od lat dwudziestych do lat osiemdziesiątych XX wieku najczęściej wybierano nazwy odzwierciedlające sowiecką rzeczywistość i wartości komunistyczne. Jako motywacyjna podstawa wyboru nominacji ukraińskich klubów piłkarskich służyły nazwy własne (nazwy stowarzyszeń sportowych, przedsiębiorstw, z imionami własnymi przywódców bolszewickich w strukturze nominacji złożonej lub bez nich), toponimy, antroponimy, jak i apelatywy (nazwy odzawodowe, nazwy rodzajów produkcji poszczególnych przedsiębiorstw).

\section{Nazwy drużyn piłkarskich w niepodległej Ukrainie}

W korpusie nazw ukraińskich drużyn piłkarskich w ciągu ostatniego ćwierćwiecza widać eklektyczny obraz nominacji, których wyboru dokonano pod wpływem czynników narodowych, totalitarnych i komercyjnych. 
3.1. Nazwy ukraińskich drużyn piłkarskich w latach dziewięćdziesiątych XX wieku i na początku XXI wieku motywowane leksyką onimiczną

Wiele klubów w nazwach wykorzystało toponimy. Tego typu nazwy, jak i sto lat temu, mają złożoną strukturę, w której połączony został skrót (SK - klub sportowy, $\mathrm{MFK}^{9}$ - miejski klub piłkarski, PFK — profesjonalny klub piłkarski, FK — klub piłkarski) i onim, na przykład MFK „Żytomyr”, MFK „Mikolajiw”, SK „Odesa” i FK „Odesa”, MFK „Oleksandria”, PFK „Oleksandria” i FK „Oleksandria”, SK „Cherson” i FK „Cherson”, PFK „Sewastopol” i FK „Sewastopol”, FK „Berszad”, FK „Boryspil”, FK „Winnycia”, FK „Dnipro” ${ }^{10}$, FK „Kałusz”, FK „Kachowka”, FK „Kowel-Wołyń”, FK „Korosteń”, FK „Krasyliw”, FK „Lwiw”, FK,Myrhorod”, FK „Petriwci”, FK,, Poltawa”, FK „Sumy”, FK „Ternopil”, FK,,Tysmenycia”, FK „Charkiw”, FK „Czerkasy”. Nazwy wielu klubów piłkarskich stanowią odzwierciedlenie nazw regionów etnograficznych Ukrainy przez nie reprezentowanych: „Bukowyna” Czerniwci, „Wołyń” Łućk, „Halyczyna” Drohobycz, „Zakarpattia” Użhorod, „Podilla” Krasyliw, „Podilla” Chmelnyćkyj, „Pokuttia” Kołomyja, „Polissia” Żytomyr, „Prykarpattia” Iwano-Frankiwsk, „Tawrija” Symferopol, „Tawrija” Cherson.

Odrębną grupę nominacji ukraińskich klubów piłkarskich obejmują nazwy własne motywowane nazwami zbiorników wodnych lub gór. Spośród hydronimów do nominacji wykorzystywano nazwy rzek występujących na terenie, z którego pochodzi klub sportowy, na przykład: „Borysfen” Boryspil (Borysfen - grecka nazwa rzeki Dniepr, Boryspil - miasto w obwodzie kijowskim, przez które przepływa Dniepr), „Worskla” Połtawa (Worskla - lewy dopływ Dniepru, Połtawa - miasto nad brzegiem Worskli), „Desna” Czernihiw (Desna - lewy dopływ Dniepru, Czernihiw miasto na prawym brzegu Desny), „Dnipro” Dnipropetrowśk, „Dnipro” Czerkasy (Dnipro - trzecia co do długości rzeka Europy, najdłuższa na Ukrainie, Dnipropetrowśk - nazwa miasta Dnipro w latach 1926-2016, położonego na obu brzegach rzeki Dniepr, Czerkasy - miasto na prawym brzegu Zbiornika Krzemieńczuckiego, utworzonego w środkowym biegu Dniepru), „Dnister” Zaliszczyky i „Dnister” Owidiopil (Dnister - rzeka w południowo-zachodniej części Ukrainy, Zaliszczyky - miasto nad brzegiem Dniestru, Owidiopil - miasto nad ujściem Dniestru), „Ikwa” Mlyniw (Ikwa - prawy dopływ Styru, Mlyniw - miasto nad rzeką Ikwą), „Inhuleć” Petrowe (Inhuleć, mały Inhuł - rzeka na południu Ukrainy, prawy dopływ Dniepru, Petrowe - miasto nad brzegiem rzeki Ingulec), „Oskil” Kupjanśk (Oskil - lewy dopływ Dońca, Kupianśk - miasto nad rzeką Oskil), „Roś” Bila Cerkwa (Roś - prawy dopływ

${ }^{9}$ Litera F w powyższych skrótach: MFK (miejski klub piłkarski), PFK (profesjonalny klub piłkarski), FK (klub piłkarski) oznacza 'futbol' - z języka ukraińskiego 'piłka nożna'.

10 Zgodnie z Ustawą o dekomunizacji Ukrainy z dnia 9 kwietnia 2016 roku nazwę miasta Dniepropietrowsk zmieniono na Dnipro. W związku z tym odpowiednio została zmodyfikowana nazwa klubu piłkarskiego „Dnipro” Dniepropietrowsk, który od rozpoczęcia sezonu 2016/2017 działa jako FK „Dnipro”. 
Dniepru, Bila Cerkwa - miasto na rzece Roś), „Sula” Lubny (Sula - lewy dopływ Dniepru, Lubny - miasto na prawym brzegu Suly).

Wśród or on imów, które znalazły odzwierciedlenie w nominacjach ukraińskich drużyn piłkarskich, należy wymienić następujące: „Haray” Żowkwa (Haray — góra w pobliżu miasta Żowkwa), „Howerla” Użhorod (Howerla - najwyższy szczyt ukraińskich Karpat położony na granicy Zakarpacia i obwodu iwano-frankowskiego, Użhorod - stolica Zakarpacia), „Karpaty” Lviv i „Karpaty” Mukaczewo (Karpaty — system górski we wschodniej części Europy Środkowej, na Ukrainie znajduje się w obrębie Zakarpacia, Bukowiny, obwodów lwowskiego i iwano-frankowskiego, Lviv - centrum administracyjne obwodu lwowskiego, Mukaczewo - miasto na Zakarpaciu), „Lysonia” Bereżany (góra Lysonia znajduje się w pobliżu miasta Bereżany); „Czornohora” Iwano-Frankiwśk (Czarnohora - najwyższy grzbiet Karpat ukraińskich, Iwano-Frankiwśk - centrum administracyjne Przykarpacia).

Odnotowano kilka antroponimów, które stały się podstawą motywacyjną nominacji klubów piłkarskich, w tym: „Prometej” Dnipropetrowśk i „Prometej” Szachtarśk (od imienia mitologicznego bohatera Prometeusza); „Helios” Charkiw (od imienia Heliosa, boga słońca w Starożytnej Grecji), „Fortuna Szarhorod (od imienia Fortuny, rzymskiej bogini szczęścia, pomyślności i sukcesu); „Tytan” Armianśk, „Tytan” Donećk (imię mitologicznego boga greckiego panteonu Tytana). Drużyna piłkarska „Wiktor” Zaporiżżia użyła w nazwie współczesnego antroponimu — imienia właściciela klubu - biznesmena, a obecnie rektora Klasycznego Prywatnego Uniwersytetu w Zaporożu Wiktora Oharenki (Вікіпедія: https:// uk.wikipedia.org).

Spośród astronimów do nazywania drużyn piłkarskich wykorzystano tylko jeden nomen - Syriusz [Sirius] — najjaśniejsza gwiazda w gwiazdozbiorze Wielkiego Psa - „Sirius” Żowti Wody, „Sirius” Krywyj Rih.

Spośród współczesnych nazw ukraińskich drużyn piłkarskich, motywowanych onimami, zachowała się część nominacji epoki sowieckiej. Przeważnie są to nazwy, których motywacyjną podstawą były nominacje stowarzyszeń sportowych: „Dynamo” - „Dynamo” Kyjiw, „Dynamo” Luhanśk, „Dynamo” Lwiw, „Dynamo” Odesa, „Dynamo” Saky, „Dynamo” Symferopol, „Dynamo” Słowianśk, „Dynamo” Chmelnyćkyj; „Spartak” - „Spartak” Iwano-Frankiwśk, „Spartak” Kałusz, „Spartak” Sumy; „Torpedo” - „Torpedo” Zaporiżżia, „Torpedo” Melitopol; „Lokomotyw” — „Lokomotyw” Smila, „Lokomotyw” Dworiczna; „Awanhard” — „Awanhard” Żydacziw, „Awanhard” Kramatorśk, „Awanhard” Merefa, „Awanhard” Roweńky; „Kolos” — „Kolos” Kowaliwka; „Hart” — „Hart” Borodianka; jak również i wojskowych stowarzyszeń sportowych: CSKA - CSKA Kyjiw; SKA — SKA Kyjiw. W wyborze nominacji zespoły nie wyszły poza ramy tradycji postkolonialnej; nazwy te są nowe dla klubów piłkarskich Kowalówki, Borodianki, Melitopola, Kałusza, Saków, Symferopolu, Słowiańska.

Kilka ukraińskich zespołów zapożyczyło swe nazwy od nominacji zagranicznych klubów piłkarskich o chwalebnej historii, z nadzieją, że ich występy w lidze 
będą tak samo udane: „Arsenał” Charkiw, „Arsenał” Bila Cerkwa (od londyńskiego Arsenalu), „Ajax” Szachtarśk (od amsterdamskiego Ajaksu), „Inter” Bojarka (od Interu Mediolan), „Real” Odesa (od Realu Madryt).

Dziedzictwem tradycji postkolonialnej w nadawaniu nazw są takie nominacje klubów piłkarskich, jak na przykład: „Drużba” Osypenko (od nazwy PGR-u Drużba 'przyjaźń, we wsi Osypenko w obwodzie zaporoskim), „Drużba” Berdianśk (następca zespołu „Drużba” Osypenko), „Illicziweć” Mariupol (klub piłkarski, który w mistrzostwach Ukrainy pojawiał się pod nazwami „Azoweć” i „Metalurh”, w jedenastym roku niepodległości został przemianowany na „Illicziweć”, od nazwy sponsora - mariupolskiego kombinatu metalurgicznego imienia Iljicza Lenina).

\subsection{Nazwy ukraińskich drużyn piłkarskich końca XX i początku XXI wieku motywowane leksyką apelatywną}

Dość liczną grupę nazw drużyn piłkarskich obejmują nominacje pochodzące od nazw obiektów przyrody oraz zjawisk natury. Przykładowo: słownictwo marynistyczne stało się podstawą motywacyjną do nazwania drużyn piłkarskich z miast położonych na Krymie na wybrzeżu Morza Czarnego: „More” Feodosija, „Ocean” Kercz. Nazwę obiektu przyrody - promienia - wykorzystano w nominacji klubu „Promiń” Wola Baranećka. Od nazw wskazujących specyficzne cechy terenów górskich pochodzą nominacje zespołów: „Beskyd” Nadwirna, „Skala” Stryj, „Skala” Morszyn i „Werchowyna” Użhorod — od werchowyna 'nazwa miejsca w ukraińskich Karpatach, położonego wysoko w górach’ (Великий тлумачний словник сучасної української мови 2001: 84). Nazwy ogólne z zakresu astronomii stały się podstawą motywacyjną dla nazw zespołów: „Zirka” [Gwiazda] Kirowohrad, „Zirka” Kropywnyćkyj, „Zorja” Luhanśk, „Kosmos” Pawlohrad.

Osobną grupę stanowią nominacje zespołów piłkarskich motywowane nazwami ptaków: „Sokil” Zolocziw (od sokoła, ale najprawdopodobniej nazwa klubu pochodzi również i od nominacji ukraińskiego towarzystwa sportowego "Sokół”, które istniało w Galicji w pierwszej połowie XX wieku), „Czajka” Sewastopol (czaj$k a$ 'mewa') oraz „Berkut” Bedewla (berkut 'orzeł przedni').

Inną grupę nazw ukraińskich drużyn piłkarskich łączą nominacje motywowane fitonimami - nazwami roślin z ukraińskich obszarów geograficznych: "Jawir” Sumy i „Jawir” Krasnopilla, pochodzące od jawir 'jawor'; czy „Weres” Riwne, wywodzący się od słowa weres 'wrzos'.

Motywacyjną podstawą do nazywania kilku zespołów piłkarskich zostały nominacje mieszkańców regionów Ukrainy, na przykład: „Azoweć” Mariupol (od azowiec 'mieszkaniec Azowa - wybrzeża Morza Azowskiego'), „Dnistroweć” Bilhorod-Dnistrowśkyj (od dniestrowiec 'mieszkaniec Białogrodu Dniestrowskiego'), „Czornomoreć” Odesa i „Czornomoreć” Sewastopol (od czornomorec 'mieszkaniec wybrzeża Morza Czarnego'). Wśród takiego typu nazw jest i całkowicie oryginalna 
— „Żytyczi” Żytomyr (od nazwy dawnego plemienia Żytyczi, które mieszkało na terenie dzisiejszego Żytomierza).

Dużą grupę nazw drużyn piłkarskich obejmują nominacje motywowane nazwami osób wykonujących różne zawody czy różną działalność: „Szachtar” Horliwka, „Szachtar” Donećk, „Szachtar” Makijiwka, „Szachtar” Pawlohrad, „Szachtar” Swerdlowśk, „Szachtar” Stachanow (od szachtar 'górnik'); „Hirnyk” Komsomolśk, „Hirnyk” Charcyz (od hirnyk 'górnik'); „Metalurh” Donećk, „Metalurh” Zaporiżżja, „Metalurh” Kercz, „Metalurh” Konsomolśke, „Metalurh” Kostiantyniwka, „Metalurh” Mariupol, „Metalurh” Nikopol, „Metalurh” Nowomoskowśk (od metalurg 'hutnik'); „Metalist” Charkiw (od metalist 'pracownik przemysłu metalowego'); „Chimik” Żytomyr, „Chimik” Kałusz, „Chimik” Krasnoperekopśk, „Chimik” Siewierodonećk (od chimik 'chemik'); „Naftowyk” Dolyna, „Naftowyk” Ochtyrka (od naftowyk 'wydobywający ropę naftową); „Maszynobudiwnyk” Drużkiwka (od maszynobudiwnyk 'producent maszyn'); „Naftochimik” Kremenczuk (od naftowyk i chimik 'pracownik przemysłu naftowego'); „Wahonobudiwnyk” Kremenczuk, „Wahonobudiwnyk” Stachanow (od wahonobudiwnyk 'producent wagonów'); „Papirnyk” Malyn (od papirnyk 'producent papieru'); „Hazowyk” Komarno (od hazowyk 'gazownik'); „Enerhetyk” Bursztyn (od enerhetyk 'energetyk'); „Meliorator” Kachowka (od meliorator 'pracownik przedsiębiorstwa melioracyjnego'); „Fetrowyk” Chust (od fetrowyk 'producent filcu'); „Medyk” Morszyn (od medyk 'specjalista medyczny'); „Chutrowyk” Tysmenycia (od chutrowyk 'kuśnierz'); „Keramik” Baraniwka (od keramik 'ceramik'); „Wodnyk” Cherson (od wodnyk 'pracownik przedsiębiorstwa wodnego'); „Portowyk” Illicziwśk, „Portowyk” Kercz (od portowyk 'doker').

Kolejną dużą grupę ukraińskich nazw drużyn piłkarskich łączą nominacje pochodzące od ergonimów - nazw firm, przedsiębiorstw finansujących kluby: "Ahrotechserwis" Sumy (od nazwy firmy Ahrotechserwis z miasta Sumy), „Adwis” Chmelnyćkyj (od nazwy fabryki Adwis w Chmielnickim), „Adoms” Kremenczuk (od nazwy domu handlowego Adoms), „Arsenal” Kyjiw (od nazwy kijowskiej fabryki Arsenal), „Bażanoweć” Makijiwka (od nazwy kopalni Makijiwwuhilla imienia Bażanowa), „Harant” Donećk (od nazwy donieckiego przedsiębiorstwa Harant), „Ewis Mykolajiw” (od nazwy spółki produkcyjno-handlowej Ewis w Mikołajowie), „Knjaża” Szczaslywe (od nazwy ukraińskiej firmy ubezpieczeniowej Knjaża), „Krymteplyća” Mołodiżne (od nazwy firmy Krymteplyća), „Lada” Czerniwci (od nazwy przedsiębiorstwa serwisu samochodowego Lada w Czerniowcach), „Medita” Szachtarśk (od nazwy Medita - kliniki medycznej, której właściciel Aleksandr Opryszczenko sponsorował zespół piłkarski), „Nafkom” Browary (od nazwy firmy Nafkom), „Oboloń” Kyjiw (od nazwy kijowskiego koncernu Oboloń), „Olimpik” Donećk (od nazwy fundacji charytatywnej, której prezes założył klub), „Olkom” Melitopol (od nazwy melitopolskiego przedsiębiorstwa produkcji mlecznej Olkom), „Piwdeństal” Jenakijewe (od nazwy koncernu metalurgicznego Piwdeństal), „Polihraftechnika” Oleksandrija (od nazwy oleksandrijskiej fabryki Polihraftechnika produkującej maszyny poligraficzne), „Rihonda” Bila Cerkwa (od nazwy przedsię- 
biorstw produkujących sprzęt audio Rihonda), „Silur” Charcyz (od nazwy fabryki Silur), „Slowjaneć” Konotop (od nazwy ukraińsko-bułgarskiego przedsiębiorstwa Slowjaneć), „Temp” Szepetiwka (od nazwy spółdzielni Temp, której prezes finansował klub piłkarski).

Oddzielną grupę tworzą nazwy motywowane leksyką apelatywną, odnoszące się do produkcji przedsiębiorstw, w których zostały utworzone drużyny piłkarskie i które to przedsiębiorstwa je sponsorowały: „Enerhija” Nowa Kachowka, „Enerhija” Jużnoukrainśk (od nazwy produkcji Kachowskiej Elektrowni Wodnej i Piwdennoukrainśkiej Elektrowni Atomowej), „Krystał” Cherson (od nazwy produkcji chersonśkiej fabryki półprzewodników), „Stal” Ałczewsk, „Stal” Dniprodzerżynśk, „Stal” Kamianśkie (od nazwy produkcji ałczewskiej i dnieprowskiej huty oraz walcowni w Dniepropietrowsku).

\subsection{Złożone nazwy drużyn piłkarskich motywowane kilkoma leksemami}

Największym eklektyzmem wyróżniają się nazwy ukraińskich zespołów niepodległej Ukrainy, które w nazwie zachowały dawną nominację i pod wpływem czynnika komercyjnego dodały do niej imię sponsora: „Worskla-Naftohaz” Połtawa (Worskla zmodyfikowała nazwę, chociaż stałym sponsorem klubu od dziesięcioleci jest Poltawhazprom), „Hazowyk-CHHW” Charkiw (nazwa uzupełniona akronimem firmy CharkiwHazWydobuwannja - CHHW), „Dynamo-IhroSerwis” Symferopol (dołączono nazwę korporacji-sponsora IhroSerwis), „Electrometalurh-NZF” Nikopol (do nazwy dodano skrót sponsora NZF - Nikopolśkyj Zawod Ferosplawiw), „Zirka-Nibas” Kirowohrad (nazwa drużyny „Zirka” w czasie, gdy klub sponsorowała firma Ahro-Nibas), „Zorja MALS” Łuhanśk (dołączono nazwę sponsora - komercyjnego przedsiębiorstwa naukowo-badawczego MALS), „Nafkom-Akademia” Irpiń (od nazwy firmy Nafkom, sponsorującej drużynę piłkarską z Narodowej Akademii Służby Podatkowej Ukrainy w Irpieniu), „Naftowyk-Ukrnafta” Ochtyrka (zespół „Naftowyk", utworzony przez zarząd firmy produkującej ropę naftową i gaz, otrzymał drugą część nazwy), „Nord-AM Podilla” Chmelnyćkyj (dodano nazwę sponsora Nord $A M$ - spółki kanadyjsko-ukraińskiej), „Systema-KCHP” Czerniachiw (nazwa zespołu piłkarskiego przy zakładzie piekarniczym - KCHP), „Slawutycz CZAES” Sławutycz (dodano akronimiczną nazwę sponsora - CZAES - Elektrowni Jądrowej w Czarnobylu), „Techno-Centr” Rohatyn (od nazwy sponsora - rohatyńskiego przedsiębiorstwa Techno-Centr), „UkrAhroKom” Hołowkiwka (wykorzystano nazwę sponsora - rolniczego holdingu UkrAhroKom), „Feniks-Illiczoweć” Kalinine (dodano nazwę sponsora - Mariupolskiego Kombinatu Metalurgicznego im. Iljicza), FK „SKIFy-LAZ” Lwiw (nazwę klubu sportowego Instytutu Wychowania Fizycznego SKIF ze Lwowa poszerzono o nazwę sponsora - LAZ, czyli Lwiwśkyj Awtobusnyj Zawod (Lwowska Fabryka Autobusów), „Cementnyk-Chorda” Mykolajiw (dodano nazwę sponsora - firmy Chorda - akcjonariusza mikołajowskiego 
zakładu cementowo-górniczego, finansującego klub na przestrzeni dziesięcioleci), CSK ZSU Kyjiw (w latach 1993-94 drużyna piłkarska CSKA nosiła nazwę Centralny Klub Sportowy Sił Zbrojnych Ukrainy, podkreślającą przynależność do ukraińskiego departamentu wojskowego), „Czajka-WMS” Sewastopol (dodano do nazwy skrót WMS - Wojskowo-Morskie Siły Zbrojne).

Inną eklektyczną grupę złożonych nominacji tworzą nazwy, w których, z przyczyn obiektywnych, połączono różne nazwy. Najczęściej były to nazwy dwóch klubów piłkarskich, które ze względu na niekorzystną sytuację finansową zostały połączone w jeden, na przykład „Awanhard-Inter” Roweńky („Awanhard” Roweńky oraz „Inter” Łuhanśk), „Awanhard-Metalist” Charkiw („Awanhard” Merefa i „Metalist” Charkiw-2), „Hazowyk-Skała” Stryj („Hazowyk” Komarno i „Skała” Stryj), „Halyczyna-Karpaty” Lwiw ( Halyczyna” Drohobycz i „Karpaty” Lwiw-3), „Dynamo-SKA” Odesa („Dynamo” i SKA z Odessy), „Nywa-Borysfen” Myroniwka („Nywa” Myroniwka i „Borysfen” Boryspil), „SKA-Lotto” Odesa (SKA i „Lotto” z Odessy), „Temp-Adwis” Szepetiwka („Temp” Szepetiwka i „Adwis” Chmelnyckyj), „CSKA-Borysfen” Boryspil (CSKA Kyjiw i „Borysfen” Boryspil).

Reasumując: należy stwierdzić, że wśród nazw ukraińskich drużyn piłkarskich w ciągu ostatnich dwóch dziesięcioleci funkcjonują nominacje motywowane różnymi nazwami: toponimami, hydronimami, oronimami, antroponimami, ergonimami i różnymi grupami apelatywów. W nazewnictwie drużyn piłkarskich okresu niepodległości Ukrainy współistnieją trzy tendencje: 1) nadawanie klubom nazw wskazujących na specyfikę narodową i kulturową Ukrainy, 2) zachowanie nominacji czasów sowieckich, przeważnie dość neutralnych, ale często nacechowanych ideologicznie, 3) tworzenie nazw eklektycznych, w których zachowano dawną nazwę zespołu (zazwyczaj nadaną w okresie od lat dwudziestych do lat osiemdziesiątych XX wieku) i dodano nazwę sponsora, co jest skutkiem komercjalizacji piłki nożnej w ciągu ostatniego ćwierćwiecza.

Ogólnie rzecz biorąc: przestrzeń onimiczna, którą tworzą nazwy ukraińskich drużyn piłkarskich przez ponad stulecie piłki nożnej na Ukrainie, to ciekawy materiał do analizy, ponieważ w nominacjach klubów piłkarskich odzwierciedlono społeczno-polityczne wydarzenia historii Ukrainy i wpływ różnych czynników na wybór nazw.

\section{Bibliografia}

Великий тлумачний словник сучасної украӥнської мови (2001): red. В.Т. Бусел, Київ-Ірпінь. Вікіпедія [електр. ресурс], Доступно з : https://uk.wikipedia.org.

Григорук Н. (2014): Власні назви польських футбольних команд: семантика, словотвір і функціонування, [w:] Польська мова в украйнській освіті - перспективи в аспекті європейської інтеграції: збірник наукових праць, red. Н. Торчинська, I. Сашко, Кельце-Хмельницький, t. 1 , s. $28-40$. 
Григорук Н. (2013): Власні назви футбольних команд Білорусі, Росії, України, „Лінгвістичні дослідження: збірник наукових праць Харківського національного педагогічного університету ім. Г.С. Сковороди", t. 36, s. 8-12.

Олейнік М. (2014): Із досліджень над хрематонімією. Зауваження щодо назв польських та українських футбольних команд, „Типологія та функції мовних одиниць: науковий журнал”, № 2, s. 198-207.

Підприємства України [електр. ресурс], Доступно 3: www.ua-region.com.ua.

Процик I.P. (2016): «Авангард», «Локомотив», «Колгоспник»: вплив тоталітаризму на вибір назв українських футбольних команд у 20-80-х рр. ХХ cm., „Наукові записки Тернопільського національного педагогічного. університету: Мовознавство”, t. 1 (25), s. 83-89.

Процик I.Р. (2016): С.Т. «Україна», У.С.К. «Тризуб», У.С.К. «Сокіл», або які назви мали українські футбольні команди Галичини в першій половині ХХ століття, „Лінгвістичні дослідження: збірник наукових праць Харківського національного педагогічного університету ім. Г.С. Сковороди", t. 43, s. 122-129.

Словник гідронімів України (1979): red. А.П. Непокупний, О.С. Стрижак, К.К. Цілуйко, Київ.

Янко М.П. (1998): Топонімічний словник України: Словник-довідник, Київ.

\section{Names of Ukrainian football teams from a historical perspective}

\section{Summary}

In this article, names of Ukrainian football teams from over a century of football history have been analyzed. The author has discussed proper names and common vocabulary that became the motivational basis for naming Ukrainian football teams. Among proper names there are state names, names of ethnographic regions of Ukraine, names of settlements - cities, towns, villages, historically important geographical names, names of rivers, names of mountains, names of people, names of sports associations, enterprises. A minor group consists of common names which are the names of the state and national symbols of Ukraine, names of lands characteristic of Ukraine, names of animals, plants, and also names of the inhabitants of different regions of Ukraine, names of people by profession or field of activity, names of products of enterprises. On the basis of the analysis of motivation of these nominations the author has shown how under the influence of the national factor, which was crucial in choosing names for football teams, the continuity of national-cultural traditions in naming has been maintained.

Keywords: onmastics, proper names of Ukrainian football teams, motivation of team names, proper name, common names vocabulary. 